\title{
Article \\ Protective Effects of Fruit Wines against Hydrogen Peroxide-Induced Oxidative Stress in Rat Synaptosomes
}

\author{
Uroš Čakar $^{1, *, \dagger}$, Mirjana Čolović ${ }^{2,+} \mathbb{D}$, Danijela Milenković ${ }^{3} \mathbb{D}$, Branislava Medić ${ }^{4}$, Danijela Krstić ${ }^{5, * \mathbb{D}}$, \\ Aleksandar Petrović ${ }^{6}$ and Brižita Đorđević ${ }^{1}$
}

1 Department of Bromatology, Faculty of Pharmacy, University of Belgrade, 11000 Belgrade, Serbia; brizita.djordjevic@pharmacy.bg.ac.rs

2 Department of Physical Chemistry, "Vinča" Institute of Nuclear Sciences-National Institute of the Republic of Serbia, University of Belgrade, 11000 Belgrade, Serbia; colovicm@vinca.rs

3 Department of Physics and Mathematics, Faculty of Pharmacy, University of Belgrade, 11000 Belgrade, Serbia; danijela.milenkovic@pharmacy.bg.ac.rs

4 Department of Pharmacology, Clinical Pharmacology and Toxicology, Faculty of Medicine, University of Belgrade, 11000 Belgrade, Serbia; brankicamedic@gmail.com

5 Faculty of Medicine, Institute of Medical Chemistry, University of Belgrade, 11000 Belgrade, Serbia

6 Faculty of Agriculture, Institute of Food Technology and Biochemistry, University of Belgrade, 11000 Belgrade, Serbia; aleksandar.petrovic@agrif.bg.ac.rs

* Correspondence: uros.cakar@pharmacy.bg.ac.rs (U.Č.); danijela.krstic@med.bg.ac.rs (D.K.)

$+\quad$ U.Č. and M.Č. have contributed equally.

check for updates

Citation: Čakar, U.; Čolović, M.; Milenković, D.; Medić, B.; Krstić, D.; Petrović, A.; Đorđević, B. Protective Effects of Fruit Wines against Hydrogen Peroxide-Induced Oxidative Stress in Rat Synaptosomes. Agronomy 2021, 11, 1414. https:// doi.org/10.3390/agronomy11071414

Academic Editors: Mirosława Chwil and Renata Matraszek-Gawron

Received: 30 May 2021

Accepted: 25 June 2021

Published: 15 July 2021

Publisher's Note: MDPI stays neutral with regard to jurisdictional claims in published maps and institutional affiliations.

Copyright: (c) 2021 by the authors. Licensee MDPI, Basel, Switzerland. This article is an open access article distributed under the terms and conditions of the Creative Commons Attribution (CC BY) license (https:// creativecommons.org/licenses/by/ $4.0 /)$.

\begin{abstract}
This study aimed to evaluate, in vitro, the antioxidative potential of fruit wines produced from berry fruits (i.e., black chokeberry, blueberry, blackberry, and raspberry), cherry, and apple by different technological processes. For this purpose, the activities of antioxidant enzymes (catalase, glutathione peroxidase (GPx), and superoxide dismutase (SOD)) and malondialdehyde (MDA) content as a marker of membrane damage were determined in wine-treated synaptosomes with hydrogen peroxide-induced oxidative stress. All studied wines induced increased antioxidant enzyme activities and decreased MDA levels compared to hydrogen peroxide-treated synaptosomes (i.e., control). The highest SOD activity was observed in synaptosomes treated with blackberry wine $(6.81 \mathrm{U} / \mathrm{mg})$, whereas blueberry wine induced the highest catalase and glutathione peroxidase activities $(0.058 \mathrm{U} / \mathrm{mg}$ and $0.017 \mathrm{U} / \mathrm{mg}$, respectively). Black chokeberry proved to be the best in lipid peroxidation protection with the lowest MDA value $(1.42 \mathrm{nmol} / \mathrm{mg})$. Finally, principal component analysis and hierarchical cluster analysis additionally highlighted a higher antioxidant capacity of wines produced from dark-skinned fruits (i.e., blackberry, black chokeberry, and blueberry). The results suggest protective effects of the fruit wines against oxidative damage, and, accordingly, their promising application as functional food.
\end{abstract}

Keywords: fruit wines; berry fruit; catalase; glutathione peroxidase; superoxide dismutase; lipid peroxidation; rat synaptosomes; in vitro antioxidative properties; principal component analysis (PCA); hierarchical cluster analysis (HCA)

\section{Introduction}

Free radicals are generated during the physiological processes in live organisms, which is a precondition for life. During evolution of the human body, there was established a system that consisted of all antioxidants involved in the protection against free radicals [1] Antioxidant enzymes are one group that constitutes this system. The most important enzymes are superoxide dismutase (SOD), catalase, and glutathione peroxidase (GPx), which prevent damage of cells by free radicals [2]. Non-enzymatic antioxidants are present, too. Among them, it is possible to highlight flavonoids, phenolic acids, vitamins, coenzyme $\mathrm{Q}$, and many others consumed daily $[1,3]$. 
In addition to the generation of free radicals during physiological processes, different factors, such as radiation, heavy metal poisoning, and poisoning with other toxicants, may be a trigger for the uncontrolled formation of free radicals [4]. When free radicals are present in high numbers, they can cause cell damage such as changes in DNA structure, membrane lipid peroxidation, and protein oxidation. They can accelerate the development of neurodegenerative diseases such as Parkinson's disease, Alzheimer's disease, multiple sclerosis, and amyotrophic lateral sclerosis [5]. Moreover, free radicals are involved in different pathological processes that cause the development of cardiovascular diseases, carcinoma, inflammations, and diabetes [6].

When it comes to the danger of free radicals, the organism certainly activates its defense system of antioxidant protection established during evolutionary development. This provides a homeostasis between the formation and neutralization of free radicals. Cells are protected against oxidative stress by increasing the activity of antioxidant enzymes [2,7]. In addition, non-enzymatic antioxidants, such as flavonoids and phenolic acids, are significantly involved, too. Flavonoids are known as good antioxidants that are able, due to the fact of their polyphenolic structure, to scavenge free radicals and chelate divalent cations $[8,9]$. Rich sources of these compounds are fruit, vegetables, nuts, seeds, and beverages (fruit wine, grape wine, as well as tea) [10-12]. The influence of active principles from fruit and wine on the enzymes of antioxidant protection is different and results in activation or inhibition of enzyme activities. Some studies revealed increased catalase activity in the presence of flavonoids [13], whereas, in others, decreased or unchanged activities were recorded [14]. The same pattern was observed in studies in which SOD and GPx activities were increased [15,16] and decreased [17] in the presence of grape wines.

The aim of this study was to evaluate the protective effects of different fruit wines produced in Serbia on hydrogen peroxide $\left(\mathrm{H}_{2} \mathrm{O}_{2}\right)$-injured rat synaptosomes in vitro. The investigated fruit wines were produced from berry fruits (i.e., black chokeberry, blueberry, blackberry, and raspberry), cherry, and apple. Technological processes applied in the production included microvinifications that were conducted with either Lievito Secco or ICV D254 yeast. The experiments were conducted with one of these two yeasts and with/without the addition of sugar and enzymatic preparation glycosidase (EPG) before the start of fermentation. The selection of the fruit wines aimed to demonstrate if the production conditions affected their antioxidant potential against $\mathrm{H}_{2} \mathrm{O}_{2}$-induced oxidative stress in isolated rat brain synaptosomes as a model system. The antioxidant capacity was assessed by following the activities of antioxidant enzymes (i.e., catalase, GPx, and SOD) and the malondialdehyde (MDA) level as an indicator of membrane lipid damage. Synaptosomes are isolated neuron terminals that functionally behave as minicells; hence, they are used as an appropriate model system for in vitro studies [18,19].

\section{Materials and Methods}

\subsection{Wine Production}

The following fruits were used for wine production: black chokeberry, blueberry, blackberry, raspberry, cherry, and apple. The experiments were conducted on the two sets [20]. The fruits were disintegrated in both sets. Ten grams of $\mathrm{K}_{2} \mathrm{~S}_{2} \mathrm{O}_{5} / 100 \mathrm{~kg}$ were subsequently added to the obtained fruit must. Total soluble solids (expressed in ${ }^{\circ}$ Brix) were measured in the fruit must of the first set. Sugar was added in the second set to increase the total soluble solids of the must up to $20.5^{\circ}$ Brix to obtain alcohol content in wines up to $12 \%$. Two sub-variants of the experiments were performed within the prior mentioned sets. In the first subset, $2 \mathrm{~g}$ of EPG/100 $\mathrm{g}$ (Enartis, Italy) was added, while in the second one it was not used. Inoculation with pure culture of commercial wine yeasts (Lievito Secco, Enartis, Italy, and ICV D254, Lallemand, Canada) was conducted respectively in both sub-sets in the amount of $20 \mathrm{~g} / 100 \mathrm{~kg}$. Both yeasts represent a Saccharomyces cerevisiae strain. Cherry was processed in the same way, with two sets of fermented musts with and without pit. Higher phenolic content was expected in the set with pit due to the extraction during fermentation in vinification watts with a pigeage 
system (Hromil, Kovilj-Serbia). Alcoholic fermentation of $25 \mathrm{~kg}$ of each fruit was conducted in watts of $30 \mathrm{~L}$ at $20^{\circ} \mathrm{C}$ over 7-10 days. Fruit must was stirred twice a day. At the end of fermentation, the pomace was separated by sedimentation from each fruit wine. Lees were removed and wines were kept at $12{ }^{\circ} \mathrm{C}$ for the next six months until further analysis.

\subsection{Chemicals and Reagents}

All chemicals were of analytical grade. Glutathione reductase from baker's yeast (Saccharomyces cerevisiae) (205 units/mg proteins, $2.2 \mathrm{mg}$ proteins $/ \mathrm{mL}$ ), reduced glutathione (GSH), EDTA, SOD determination kit, NADH, NADPH, thiobarbituric acid (TBA), and Folin-Ciocalteu reagent were from Sigma-Aldrich (Steinheim, Germany). Other reagents, such as sodium dihydrogen phosphate, sodium hydrogen phosphate, sodium carbonate, sucrose, hydrochloric acid, and n-butanol, were obtained from Merck (Darmstadt, Germany).

\subsection{Lyophilization of Fruit Wines}

Fruit wines were lyophilized in order to avoid the influence of ethanol on enzyme activities and lipid peroxidation during the experiment. The lyophilization was carried out under the pressure and temperature of $0.30 \mathrm{mbar}$ and $-55^{\circ} \mathrm{C}$, respectively, for $9 \mathrm{~h}$ using the laboratory freeze-dryer, Christ Alpha 1-2/LD plus (Osterode am Harz, Germany) (main drying time: $8.5 \mathrm{~h}$; final drying: $30 \mathrm{~min}$ ). The obtained lyophilized wine samples were used for further analysis.

\subsection{Preparation of Crude Synaptosomal Fraction}

Isolation of synaptosomes was conducted from the whole brains of Wistar albino rats by following a previously published method [21,22]. Guidelines from the European Convention for the Protection of Vertebrate Animals Used for Experimental and Other Scientific Purposes, Directive 2010/63/EU, and Good Laboratory Practice were fully followed. Decapitation was carried out with a guillotine (Harvard Apparatus, Holliston, MA, USA). Then, each brain was extracted, cut out, and homogenized in $10 \mathrm{~mL}$ of the solution containing $0.32 \mathrm{M}$ sucrose and $10 \mathrm{mM}$ Tris- $\mathrm{HCl}(\mathrm{pH}$ 7.4). After centrifugation of the homogenates at $1000 \times g$ for $10 \mathrm{~min}$ at $4{ }^{\circ} \mathrm{C}$, the obtained supernatants were transferred to new tubes, and the remaining pellets were resuspended in the homogenization solution and centrifuged as described. Two collected supernatant fractions were merged and centrifuged at $10,000 \times g$ for $20 \mathrm{~min}$ at $4^{\circ} \mathrm{C}$. Precipitated pellets of crude synaptosomes were resuspended in $3 \mathrm{~mL}$ of buffered $0.32 \mathrm{M}$ sucrose, then combined and divided into the appropriate number of aliquots that were freshly used for subsequent treatment.

\subsection{Synaptosomal Treatment with Fruit Wines}

The lyophilized fruit wine samples $(60 \mathrm{mg})$ were dissolved in $600 \mu \mathrm{L}$ of distilled water. The prepared wine solutions were added to $3 \mathrm{~mL}$ of the synaptosomal preparation and were incubated at $37{ }^{\circ} \mathrm{C}$ for $10 \mathrm{~min}$, before the addition of $\mathrm{H}_{2} \mathrm{O}_{2}$ (final concentration of $400 \mu \mathrm{M})$ [23]. The incubation was then allowed to continue for $1 \mathrm{~h}$ at $37^{\circ} \mathrm{C}$, and the treated synaptosomes were used for the determination of antioxidant enzyme activities and lipid peroxidation level. In addition, the aliquot of synaptosomal preparation was incubated in the presence of $\mathrm{H}_{2} \mathrm{O}_{2}\left(1 \mathrm{~h}, 37^{\circ} \mathrm{C}\right)$, which served as a control sample.

\subsection{Determination of Antioxidant Enzyme Activities}

For determination of catalase activity, an $\mathrm{H}_{2} \mathrm{O}_{2}$ degradation assay was employed [24]. The $50 \mu \mathrm{L}$ of crude synaptosomal preparation was added to a quartz cuvette (room temperature) that contained $2.975 \mathrm{~mL}$ of $0.05 \mathrm{M}$ sodium phosphate buffer ( $\mathrm{pH} 7.0$ ) and $0.4 \mathrm{mM}$ EDTA. Then, $30 \mu \mathrm{L}$ of $3 \% \mathrm{H}_{2} \mathrm{O}_{2}$ was added to initiate the enzyme reaction. The absorbance decrease $\left(\mathrm{H}_{2} \mathrm{O}_{2}\right.$ degradation) was followed at $240 \mathrm{~nm}$ for $5 \mathrm{~min}$, as a measure of catalase activity that was expressed as $\mathrm{U} / \mathrm{mg}$ protein. One unit (U) was defined as $1 \mu \mathrm{mol}$ of $\mathrm{H}_{2} \mathrm{O}_{2}$ consumed/min. 
The GPx activity was determined according to a slight modified coupled enzyme method following the decrease in NADPH at $340 \mathrm{~nm}$ [25]. A reaction mixture contained $8.9 \mathrm{~mL}$ of $0.05 \mathrm{M}$ sodium phosphate buffer with $0.1 \mathrm{mM}$ of EDTA (pH 7.0), $50 \mathrm{~mL}$ of $200 \mathrm{mM}$ GSH, $100 \mathrm{~mL}$ of glutathione reductase (100 units/mL), and $1 \mathrm{mg}$ NADPH. After starting the enzyme reaction by the addition of $300 \mathrm{~mL}$ of synaptosomal preparation and $50 \mathrm{~mL}$ of $0.042 \% \mathrm{H}_{2} \mathrm{O}_{2}$ (freshly prepared) to $3 \mathrm{~mL}$ of the reaction mixture, an absorbance decrease was followed for $5 \mathrm{~min}$. The GPx activity was expressed as U/mg protein. One unit (U) was defined as the amount of the enzyme that catalyzed the oxidation of $1.0 \mathrm{mmol}$ of $\mathrm{GSH}$ by $\mathrm{H}_{2} \mathrm{O}_{2}$ per minute.

A commercially available SOD Assay Kit (code 19160, Sigma Aldrich, Hamburg, Germany) was used for the determination of total SOD activity expressed as $\mathrm{U} / \mathrm{mg}$ protein.

\subsection{Lipid Peroxidation Assay}

The level of lipid peroxidation was evaluated according to the published method [26]. The volume of $0.5 \mathrm{~mL}$ of the synaptosomal preparation was mixed with $0.5 \mathrm{~mL}$ of TBA in $0.05 \mathrm{M} \mathrm{NaOH}$ and $0.5 \mathrm{~mL}$ of $25 \% \mathrm{HCl}$, and then heated in boiling water for $10 \mathrm{~min}$. After cooling, $3 \mathrm{~mL}$ of $\mathrm{n}$-butanol was added to extract the chromogen in the organic phase that was separated by centrifugation at $2000 \times g$ for $10 \mathrm{~min}$ and used for spectrophotometric reading of absorbance at $532 \mathrm{~nm}$. The level of lipid peroxidation was expressed as nmol of thiobarbituric acid-reactive substance (MDA equivalent)/mg protein, using a standard curve of 1,1,3,3-tetramethoxypropane.

Total protein concentration in synaptosomal fraction was quantified by the procedure of Lowry's method [27] using Folin's reagent, and bovine serum albumin as a standard.

\subsection{Statistical Analysis}

Statistical analysis was conducted using the software SPSS Statistic V22.0 (IBM, Chicago, IL, USA; 2014). To show significant differences between values of parameters of oxidative stress in $\mathrm{H}_{2} \mathrm{O}_{2}$-injured synaptosomes treated with lyophilized fruit wines produced by different technological processes, paired sample $t$-tests were applied. Correlation between parameters of oxidative stress and antioxidant properties were shown by principal component analysis (PCA) and hierarchical cluster analysis (HCA).

\section{Results and Discussion}

3.1. Effect of Various Types of Fruit Wines on the Activities of Antioxidant Enzymes and Lipid Peroxidation in $\mathrm{H}_{2} \mathrm{O}_{2}$-Treated Synaptosomes

The cctivity of SOD was determined in the wine-treated synaptosomes with $\mathrm{H}_{2} \mathrm{O}_{2}$-induced oxidative stress for different kinds of fruit and microvinifications (Table 1). The obtained results indicate that the highest SOD activities $(6.53$ and $6.81 \mathrm{U} / \mathrm{mg}$ protein for Lievito Secco and ICV D254, respectively) were observed in synaptosomes treated with blackberry wine with added sugar and enzyme (+sugar, +enzyme), whereas apple wine with no added sugar and enzyme before the fermentation (-sugar, - enzyme) exhibited the lowest SOD values (4.67 and $4.58 \mathrm{U} / \mathrm{mg}$ protein for Lievito Secco and ICV D254, respectively) (Table 1). Moreover, when comparing the SOD activities of the fruit wines that were produced with added sugar and enzyme (+sugar, +enzyme) with the values of the corresponding ones produced without added sugar and enzyme (-sugar, - enzyme), a statistically significant difference $(p<0.05)$ can be noticed for all investigated fruit wine samples, for both yeasts applied (Table 1). It is worthy to remark that all tested fruit wines induced an increase in SOD activities related to a control value $(4.51 \pm 0.35 \mathrm{U} / \mathrm{mg}$ protein) obtained for $\mathrm{H}_{2} \mathrm{O}_{2}$-treated synaptosomes. 
Table 1. The specific activities of SOD (U/mg protein) obtained for wine-treated synaptosomes with $\mathrm{H}_{2} \mathrm{O}_{2}$-induced oxidative stress for different types of fruit wines and microvinification.

\begin{tabular}{|c|c|c|c|}
\hline \multirow{2}{*}{$\begin{array}{c}\text { Type of } \\
\text { Fruit }\end{array}$} & \multirow{2}{*}{$\begin{array}{c}\text { Type of } \\
\text { Microvinification }\end{array}$} & $\begin{array}{c}\text { Lievito Secco } \\
\text { Yeast }\end{array}$ & $\begin{array}{c}\text { ICV D254 } \\
\text { Yeast }\end{array}$ \\
\hline & & U/mg Protein & U/mg Protein \\
\hline $\begin{array}{c}\text { Black } \\
\text { chokeberry }\end{array}$ & $\begin{array}{c}\text { - sugar } \\
\text { - enzyme }\end{array}$ & $5.81 \pm 0.50$ & $5.95 \pm 0.55$ \\
\hline $\begin{array}{c}\text { Black } \\
\text { chokeberry }\end{array}$ & $\begin{array}{c}\text { +sugar } \\
\text { +enzyme }\end{array}$ & $6.26 \pm 0.62^{\mathrm{a}, *}$ & $6.22 \pm 0.52^{b, *}$ \\
\hline Blueberry & $\begin{array}{l}\text { - sugar } \\
\text { - enzyme }\end{array}$ & $6.08 \pm 0.45$ & $5.86 \pm 0.40$ \\
\hline Blueberry & $\begin{array}{c}\text { +sugar } \\
\text { +enzyme }\end{array}$ & $6.35 \pm 0.50^{a, *}$ & $6.22 \pm 0.56^{\mathrm{b}, *}$ \\
\hline Blackberry & $\begin{array}{l}\text { - sugar } \\
\text { - enzyme }\end{array}$ & $6.17 \pm 0.47$ & $6.26 \pm 0.51$ \\
\hline Blackberry & $\begin{array}{l}\text { +sugar } \\
\text { +enzyme } \\
\text { - sugar }\end{array}$ & $6.53 \pm 0.62^{a, *}$ & $6.81 \pm 0.65^{b, *}$ \\
\hline Cherry & $\begin{array}{c}\text { - enzyme } \\
\text { - pit } \\
\text { +sugar }\end{array}$ & $5.45 \pm 0.48$ & $5.59 \pm 0.55$ \\
\hline Cherry & $\begin{array}{c}\text { +enzyme } \\
+ \text { pit }\end{array}$ & $5.63 \pm 0.52^{\mathrm{a}, *}$ & $5.50 \pm 0.58^{b, *}$ \\
\hline Raspberry & $\begin{array}{l}\text { - sugar } \\
\text { - enzyme }\end{array}$ & $5.23 \pm 0.49$ & $5.01 \pm 0.38$ \\
\hline Raspberry & $\begin{array}{c}\text { +sugar } \\
\text { +enzyme }\end{array}$ & $5.09 \pm 0.41^{\mathrm{a}, *}$ & $5.32 \pm 0.40^{\mathrm{b}, *}$ \\
\hline Apple & $\begin{array}{l}\text { - sugar } \\
\text { - enzyme }\end{array}$ & $4.67 \pm 0.38$ & $4.58 \pm 0.42$ \\
\hline Apple & $\begin{array}{c}\text { +sugar } \\
+ \text { enzyme }\end{array}$ & $4.79 \pm 0.40^{\mathrm{a}, *}$ & $4.73 \pm 0.45^{\mathrm{b}, *}$ \\
\hline
\end{tabular}

a Statistically significant difference from wine produced without the addition of sugar and enzyme (-sugar, -enzyme) with Lievito Secco; ${ }^{b}$ statistically significant difference from wine produced without the addition of sugar and enzyme (-sugar, - enzyme) with ICV D254; ${ }^{*} p<0.05$. Control value $=4.51 \pm 0.35 \mathrm{U} / \mathrm{mg}$.

The data in the literature indicated that blackberry extract showed good ex vivo and in vivo activities in the protection against oxidative stress in a rat liver model. In this study, increased activities of SOD, catalase, and GPx were confirmed in cells with $\mathrm{CCl}_{4}$-induced oxidative stress [28]. Furthermore, a study conducted in healthy volunteers showed that intake of dealcoholized red wine increased SOD and catalase activities, whereas it did not influence GPx activity [29].

Catalase activity was determined in fruit wine-treated synaptosomes with $\mathrm{H}_{2} \mathrm{O}_{2}$-induced oxidative stress (Table 2). It can be observed that all studied fruit wines induced a catalase activation related to a control $>0.0326 \mathrm{U} / \mathrm{mg}$ protein. Blueberry wine (+sugar, +enzyme, Lievito Secco yeast) treatment resulted in the highest increase of catalase activity $(0.058 \mathrm{U} / \mathrm{mg}$ protein). On the other hand, the weakest effect was remarked for apple wine (-sugar, - enzyme, ICV D254 yeast), 0.034 vs. $0.0326 \mathrm{U} / \mathrm{mg}$ protein, as obtained for SOD activity. Furthermore, a statistically significant increase $(p<0.05)$ in catalase activities was obtained for microvinification performed with the added enzyme and sugar (+sugar, +enzyme), compared with the corresponding values for all fruit wines produced without the initial addition of enzyme and sugar (-sugar, - enzyme) (Table 2). 
Table 2. Specific activities of catalase (U/mg protein) in wine-treated synaptosomes with $\mathrm{H}_{2} \mathrm{O}_{2}$-induced oxidative stress obtained for different types of fruit wines and microvinification.

\begin{tabular}{|c|c|c|c|}
\hline \multirow{2}{*}{$\begin{array}{l}\text { Type of } \\
\text { Fruit }\end{array}$} & \multirow{2}{*}{$\begin{array}{c}\text { Type of } \\
\text { Microvinification }\end{array}$} & $\begin{array}{c}\text { Lievito Secco } \\
\text { Yeast }\end{array}$ & $\begin{array}{l}\text { ICV D254 } \\
\text { Yeast }\end{array}$ \\
\hline & & U/mg Protein & U/mg Protein \\
\hline $\begin{array}{c}\text { Black } \\
\text { chokeberry }\end{array}$ & $\begin{array}{c}\text { - sugar } \\
\text { - enzyme }\end{array}$ & $0.041 \pm 0.005$ & $0.042 \pm 0.004$ \\
\hline $\begin{array}{c}\text { Black } \\
\text { chokeberry }\end{array}$ & $\begin{array}{l}\text { +sugar } \\
+ \text { enzyme }\end{array}$ & $0.049 \pm 0.005^{\mathrm{a}, *}$ & $0.048 \pm 0.004^{\mathrm{b}, *}$ \\
\hline Blueberry & $\begin{array}{l}\text { - sugar } \\
\text { - enzyme }\end{array}$ & $0.047 \pm 0.005$ & $0.043 \pm 0.004$ \\
\hline Blueberry & $\begin{array}{l}\text { +sugar } \\
\text { +enzyme }\end{array}$ & $0.058 \pm 0.004^{\mathrm{a}, *}$ & $0.054 \pm 0.005^{b, *}$ \\
\hline Blackberry & $\begin{array}{c}\text { - sugar } \\
\text { - enzyme }\end{array}$ & $0.042 \pm 0.004$ & $0.043 \pm 0.004$ \\
\hline Blackberry & $\begin{array}{l}\text { +sugar } \\
\text { +enzyme } \\
\text { - sugar }\end{array}$ & $0.051 \pm 0.005^{\mathrm{a}, *}$ & $0.050 \pm 0.004^{\mathrm{b}, *}$ \\
\hline Cherry & $\begin{array}{c}\text { - enzyme } \\
\text { - pit } \\
\text { +sugar }\end{array}$ & $0.034 \pm 0.003$ & $0.035 \pm 0.004$ \\
\hline Cherry & $\begin{array}{l}\text { +enzyme } \\
+ \text { pit }\end{array}$ & $0.039 \pm 0.003^{a, *}$ & $0.037 \pm 0.004^{b, *}$ \\
\hline Raspberry & $\begin{array}{l}\text { - sugar } \\
\text { - enzyme }\end{array}$ & $0.035 \pm 0.003$ & $0.036 \pm 0.003$ \\
\hline Raspberry & $\begin{array}{c}\text { +sugar } \\
\text { +enzyme }\end{array}$ & $0.039 \pm 0.004^{\mathrm{a}, *}$ & $0.040 \pm 0.003^{b, *}$ \\
\hline Apple & $\begin{array}{c}\text { - sugar } \\
\text { - enzyme }\end{array}$ & $0.036 \pm 0.003$ & $0.034 \pm 0.003$ \\
\hline Apple & $\begin{array}{l}\text { +sugar } \\
+ \text { enzyme }\end{array}$ & $0.038 \pm 0.003^{\mathrm{a}, *}$ & $0.039 \pm 0.004^{b, *}$ \\
\hline
\end{tabular}

a Statistically significant difference from wine produced without the addition of sugar and enzyme (-sugar - enzyme) with Lievito Secco; ${ }^{b}$ statistically significant difference from wine produced without the addition of sugar and enzyme (-sugar, - enzyme) with ICV D254; * $p<0.05$. Control value $=0.0326 \pm 0.003 \mathrm{U} / \mathrm{mg} \mathrm{protein}$.

Blackberry and raspberry extracts were found to be a good source of biologically active compounds essential for antioxidant protection. Corresponding berry extracts increased SOD and catalase activities, which decreased oxidative stress-induced damage in gastric mucosa cells of animal models [30]. A study showed that catechin and hydroxybenzoic acid derivatives from white wine extracts can pass the blood-brain barrier. Their presence in brain cells increased catalase activity and decreased lipid oxidation in cell membrane [31].

Specific GPx activity was determined in $\mathrm{H}_{2} \mathrm{O}_{2}$-injured synaptosomes treated with the studied fruit wines (Table 3). The highest GPx activity was obtained in synaptosomes treated with blueberry wine $(0.017 \mathrm{U} / \mathrm{mg}$ protein $)$, whereas the lowest value was observed for cherry (0.00972 U/mg protein) (Table 3). As in the case of both SOD and catalase, the wine treatment resulted in an increase of synaptosomal GPx activity related to the control (0.00901 U/mg protein) for all tested wines and fermentation conditions. In addition, the technological process of production in which enzyme and sugar were added before the start of fermentation (+enzyme, +sugar) showed a statistically significant difference $(p<0.05)$ (Table 3). A study conducted in Serbia with healthy volunteers showed that intake of black chokeberry products over three months increased both SOD and GPx activities in erythrocytes [32]. 
Table 3. Specific activities of GPx (U/mg protein) in fruit wine-treated synaptosomes with $\mathrm{H}_{2} \mathrm{O}_{2}$ induced oxidative stress obtained for different types of fruit wines and microvinification.

\begin{tabular}{|c|c|c|c|}
\hline \multirow{2}{*}{$\begin{array}{l}\text { Type of } \\
\text { Fruit }\end{array}$} & \multirow{2}{*}{$\begin{array}{c}\text { Type of } \\
\text { Microvinification }\end{array}$} & $\begin{array}{c}\text { Lievito Secco } \\
\text { Yeast }\end{array}$ & $\begin{array}{l}\text { ICV D254 } \\
\text { Yeast }\end{array}$ \\
\hline & & U/mg Protein & U/mg Protein \\
\hline $\begin{array}{c}\text { Black } \\
\text { chokeberry }\end{array}$ & $\begin{array}{l}\text { - sugar } \\
\text { - enzyme }\end{array}$ & $0.0147 \pm 0.002$ & $0.0141 \pm 0.001$ \\
\hline $\begin{array}{c}\text { Black } \\
\text { chokeberry }\end{array}$ & $\begin{array}{c}\text { +sugar } \\
\text { +enzyme }\end{array}$ & $0.0163 \pm 0.002^{\mathrm{a}, *}$ & $0.0159 \pm 0.002^{b, *}$ \\
\hline Blueberry & $\begin{array}{l}\text { - sugar } \\
\text { - enzyme }\end{array}$ & $0.0153 \pm 0.002$ & $0.0148 \pm 0.002$ \\
\hline Blueberry & $\begin{array}{c}\text { +sugar } \\
+ \text { enzyme }\end{array}$ & $0.017 \pm 0.002^{a, *}$ & $0.0166 \pm 0.002^{b, *}$ \\
\hline Blackberry & $\begin{array}{c}\text { - sugar } \\
\text { - enzyme }\end{array}$ & $0.0158 \pm 0.002$ & $0.0138 \pm 0.001$ \\
\hline Blackberry & $\begin{array}{l}\text { +sugar } \\
\text { +enzyme } \\
\text {-sugar }\end{array}$ & $0.0142 \pm 0.002^{\mathrm{a}, *}$ & $0.0155 \pm 0.002^{b, *}$ \\
\hline Cherry & $\begin{array}{c}\text { - enzyme } \\
\text { - pit } \\
\text { +sugar }\end{array}$ & $0.00972 \pm 0.001$ & $0.0099 \pm 0.001$ \\
\hline Cherry & $\begin{array}{l}\text { +enzyme } \\
+ \text { pit }\end{array}$ & $0.0105 \pm 0.001^{\mathrm{a}, *}$ & $0.0110 \pm 0.001^{b, *}$ \\
\hline Raspberry & $\begin{array}{c}\text { - sugar } \\
\text { - enzyme }\end{array}$ & $0.0128 \pm 0.001$ & $0.0131 \pm 0.001$ \\
\hline Raspberry & $\begin{array}{l}\text { +sugar } \\
\text { +enzyme }\end{array}$ & $0.0137 \pm 0.002^{a, *}$ & $0.0141 \pm 0.002^{b, *}$ \\
\hline Apple & $\begin{array}{l}\text { - sugar } \\
\text { - enzyme }\end{array}$ & $0.0117 \pm 0.001$ & $0.0112 \pm 0.001$ \\
\hline Apple & $\begin{array}{c}\text { +sugar } \\
\text { +enzyme }\end{array}$ & $0.0121 \pm 0.001^{\mathrm{a}, *}$ & $0.0125 \pm 0.001^{\mathrm{b}, *}$ \\
\hline
\end{tabular}

$\bar{a}$ Statistically significant difference from wine produced without the addition of sugar and enzyme (-sugar, - enzyme) with Lievito Secco; ${ }^{\text {b }}$ statistically significant difference from wine produced without the addition of sugar and enzyme (-sugar, - enzyme) with ICV D254; ${ }^{*} p<0,05$. Control value $=0.00901 \pm 0.001 \mathrm{U} / \mathrm{mg}$ protein.

The effect of synaptosomal exposure to fruit wines produced by different technological processes on MDA content, as a marker of lipid peroxidation and membrane damage, was determined (Table 4). In the presence of all analyzed wine samples, MDA values were found to be lower related to $\mathrm{H}_{2} \mathrm{O}_{2}$-treated synaptosomes (control, $3.78 \mathrm{nmol} / \mathrm{mg}$ protein). The lowest MDA level (1.42 nmol/mg protein) was observed for black chokeberry wine fermented with added enzyme and sugar (+sugar, +enzyme), and apple wine treatment resulted in the highest synaptosomal content of MDA (Table 4). Moreover, a statistically significant difference was obtained for different types of microvinification $(+/-$ sugar, enzyme) of one fruit species.

The data in the literature indicated that blueberry extract decreased MDA levels in the brains of experimental animals [33]. Moreover, orally administrated dealcoholized grape wine extract significantly decreased serum MDA levels and affected blood vessel relaxation in experimental animals [34].

As highlighted above, the technological process of production in which EPG and sugar were added before the start of fermentation showed statistically significant difference for all measured parameters $(p<0.05)$. On the contrary, the usage of different yeasts in microvinification did not show statistical significance $(p>0.05)$ for the activity of the selected enzymes and MDA values. 
Table 4. MDA content (nmol/mg protein) in synaptosomes with $\mathrm{H}_{2} \mathrm{O}_{2}$-induced oxidative stress obtained in the presence of fruit wines produced by different types of microvinification.

\begin{tabular}{|c|c|c|c|}
\hline \multirow{2}{*}{$\begin{array}{c}\text { Type of } \\
\text { Fruit }\end{array}$} & \multirow{2}{*}{$\begin{array}{c}\text { Type of } \\
\text { Microvinification }\end{array}$} & $\begin{array}{c}\text { Lievito Secco } \\
\text { Yeast }\end{array}$ & $\begin{array}{l}\text { ICV D254 } \\
\text { Yeast }\end{array}$ \\
\hline & & $\begin{array}{l}\text { nmol/mg } \\
\text { Protein }\end{array}$ & $\begin{array}{c}\mathrm{nmol} / \mathrm{mg} \\
\text { Protein }\end{array}$ \\
\hline $\begin{array}{c}\text { Black } \\
\text { chokeberry }\end{array}$ & $\begin{array}{c}\text { - sugar } \\
\text {-enzyme }\end{array}$ & $1.65 \pm 0.15$ & $1.74 \pm 0.14$ \\
\hline $\begin{array}{c}\text { Black } \\
\text { chokeberry }\end{array}$ & $\begin{array}{l}\text { +sugar } \\
\text { +enzyme }\end{array}$ & $1.42 \pm 0.11^{\mathrm{a}, *}$ & $1.50 \pm 0.12^{b, *}$ \\
\hline Blueberry & $\begin{array}{c}\text { - sugar } \\
\text { - enzyme }\end{array}$ & $2.69 \pm 0.22$ & $2.57 \pm 0.15$ \\
\hline Blueberry & $\begin{array}{c}\text { +sugar } \\
+ \text { enzyme }\end{array}$ & $2.25 \pm 0.18^{a, *}$ & $2.32 \pm 0.17^{b, *}$ \\
\hline Blackberry & $\begin{array}{l}\text { - sugar } \\
\text { - enzyme }\end{array}$ & $2.15 \pm 0.16$ & $2.31 \pm 0.18$ \\
\hline Blackberry & $\begin{array}{l}\text { +sugar } \\
\text { +enzyme } \\
\text { - sugar }\end{array}$ & $1.63 \pm 0.16^{\mathrm{a}, *}$ & $1.85 \pm 0.15^{b, *}$ \\
\hline Cherry & $\begin{array}{l}\text { - enzyme } \\
\text { - pit } \\
\text { +sugar }\end{array}$ & $1.91 \pm 0.15$ & $1.79 \pm 0.12$ \\
\hline Cherry & $\begin{array}{l}\text { +enzyme } \\
+ \text { pit }\end{array}$ & $1.72 \pm 0.14^{\mathrm{a}, *}$ & $1.85 \pm 0.13^{b, *}$ \\
\hline Raspberry & $\begin{array}{l}\text { - sugar } \\
\text {-enzyme }\end{array}$ & $2.91 \pm 0.25$ & $2.62 \pm 0.14$ \\
\hline Raspberry & $\begin{array}{c}\text { +sugar } \\
\text { +enzyme }\end{array}$ & $2.52 \pm 0.13^{a, *}$ & $2.43 \pm 0.15^{b, *}$ \\
\hline Apple & $\begin{array}{l}\text { - sugar } \\
\text { - enzyme }\end{array}$ & $3.49 \pm 0.22$ & $3.37 \pm 0.25$ \\
\hline Apple & $\begin{array}{c}\text { +sugar } \\
\text { +enzyme }\end{array}$ & $3.62 \pm 0.20^{a, *}$ & $3.52 \pm 0.23^{b, *}$ \\
\hline
\end{tabular}

a Statistically significant difference from wine produced without the addition of sugar and enzyme (-sugar, -enzyme) with Lievito Secco; ${ }^{b}$ statistically significant difference from wine produced without the addition of sugar and enzyme (-sugar, -enzyme) with ICV D254; ${ }^{*} p<0.05$. Control value $=3.78 \pm 0.25 \mathrm{nmol} / \mathrm{mg}$ protein

In this study, the wine lyophilizates were used for the antioxidant activity assessment of the analyzed fruit wines, which were reported to have almost identical polyphenolic contents compared to wines before lyophilization [35] and are suitable for in vitro evaluation of wine bioactivity $[35,36]$. The obtained results can be explained by the fact that antioxidant compounds in wine affected the activities of the antioxidant enzymes and reduced MDA content in the treated synaptosomes. Our prior study [20] analyzed the phenolic profile of fruit wines that were used for the treatment of synaptosomes in this study. The results indicated that the most predominant compounds were phenolic acids (i.e., chlorogenic, caffeic, and gallic acid) and flavonoids (i.e., catechin and epicatechin). These findings are in agreement with literature data reporting chlorogenic acid as a leading compound in berry fruits with dark skin. Among them, it is possible to highlight blueberry which has fruits and wine that were shown to be a rich source of the aforementioned phenolic acids [37-39]. The observed high content of chlorogenic, caffeic, and other phenolic acids [20] is in line with the literature regarding black chokeberry wine [40,41] and fruit [38]. Furthermore, the study on Croatian blackberry wines highlighted gallic acid as a major compound [42], while chlorogenic and other phenolic acids were found as well [43]. The dominant content of gallic acid in raspberry [20] is supported by the literature [44,45]. In addition to phenolic acids, berries were confirmed as a rich source of epicatechin and catechin [46,47]. In comparison with red grape, berry fruits (i.e., black chokeberry, blueberry, and blackberry) have a similar or even higher content of phenolic compounds [48]. Cherry wine was also 
revealed in our previous study [20] as a rich source of phenolic acids, with chlorogenic acid as the most abundant, which is in accordance with other studies $[49,50]$.

During the production of wine, biologically active compounds (with an emphasis on flavonoids and phenolic acids) are liberated from fruit into the ethanolic-water solution, which improves their bioavailability [51]. During alcoholic fermentation of fruit juice, the content of phenolic compounds increases due to the extraction from solid parts of fruit (i.e., skin and seeds) [52]. Vinification is a process that involves many biochemical reactions conducted under the activity of pure yeast cultures, mostly from the Saccharomyces cerevisiae strain, which play a key role during alcoholic fermentation [53]. It is important to highlight that increased sugar content resulted in a higher level of alcohol in the final product-fruit wine, which actually influenced better extraction of antioxidants. Moreover, EPG addition increased aglycone content (with an emphasis on flavonoids and phenolic acids) as key bioactive principles. The obtained results are in agreement with our previous study in which wines produced from berry fruits with dark skin (i.e., black chokeberry, blueberry, and blackberry) showed significantly higher content of selected phenolic compounds and, accordingly, higher antioxidant activity [20]. The activity of EPG increased the content of resveratrol free isomers in grape wines [54]. The content of phenolic compounds in fruit wines depends on different factors such as fruit cultivar, duration of maceration, climate, transport, and storage of fruit [52]. Literature data indicate that flavonoid aglycons possess good free radical scavenging activities, a capability to chelate metal ions, and to protect human health in general [29]. In cell lines that were exposed to herbal extract rich in flavonoid aglycones, free radical generation and MDA levels decreased, whereas an increase in SOD, catalase, and GPx activities was noticed. The observed activities confirm the protective effects of flavonoid aglycones, which is in agreement with their antioxidant properties [55].

\subsection{Correlation between Parameters of Oxidative Stress and Antioxidant Properties-PCA Analysis}

The obtained results for parameters of oxidative stress (i.e., SOD, CAT, GPx, and MDA) (Tables 1-4), and values for ferric reducing/antioxidant power (FRAP), 2,2-diphenyl-1picrylhydrazyl (DPPH) free radical scavenging potency, and total phenolic content (TPC) obtained from our previous study [20] were analyzed with PCA. Analysis was conducted for wine samples produced with Lievito Secco and ICV D254 yeast.

After conducting a PCA analysis of the wines produced with Lievito Secco yeast, it was possible to highlight two separate components with a cumulative diversity of $88.09 \%$. The value of the first component was 4964 , which explained $70.91 \%$ of the diversity, while the value for the second component was 1202, which explained $17.17 \%$ of the diversity. The first component, which showed the highest value, described more variables in the PCA analysis, while the second one described less. To make better interpretability with these two components, rotation was applied to achieve maximal availability of both components to explain the existing variables. Orthogonal varimax rotation was applied, since it maximally describes variance with new components. After rotation, it was noticed that the first component better described variables of MDA, DPPH, and TPC, while the second component better described CAT, GPx, FRAP, and SOD. It is possible to notice in Figure 1 that wines made from black chokeberry, blueberry, and blackberry were clearly grouped. These wines showed high values for FRAP, DPPH, and TPC and also highly increased the activity of antioxidant enzymes (SOD, GPx, and CAT) and decreased MDA values. The second group consisted of wines produced from cherry, raspberry, and apple. These wines significantly less affected the activity of antioxidant enzymes and decreased MDA values. The values for FRAP, DPPH, and TPC for wines in the second group were much lower than in the first. 


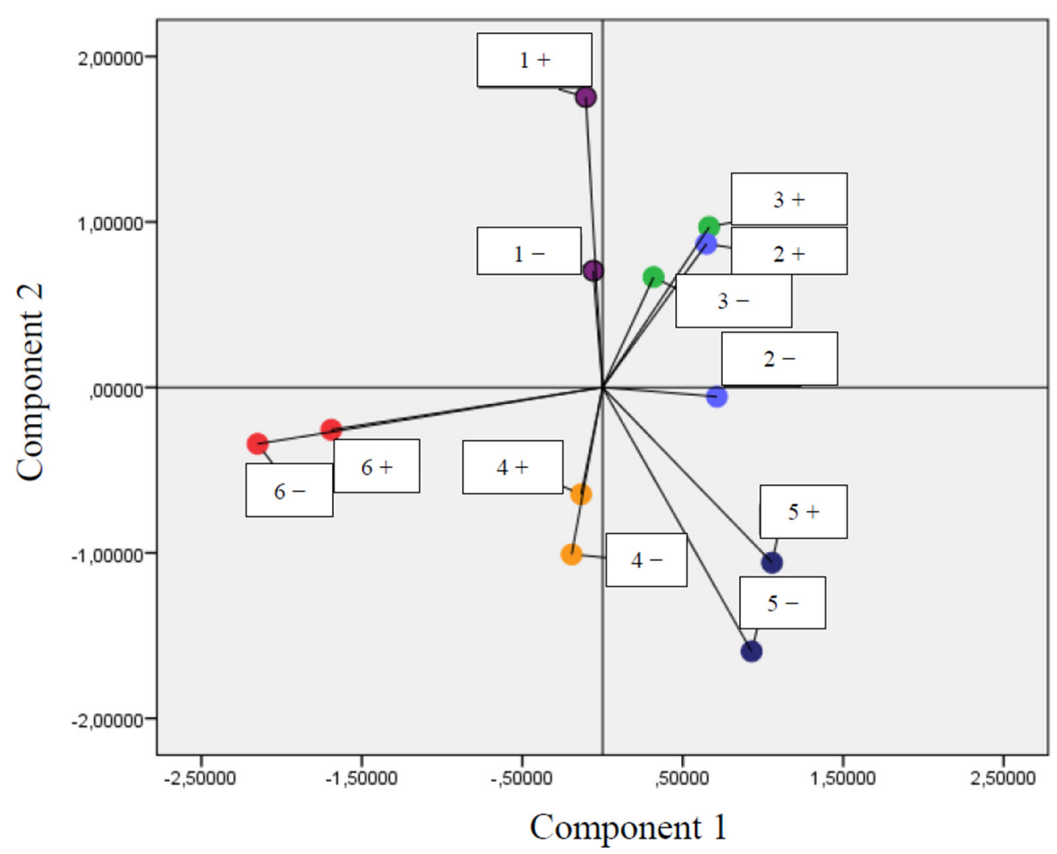

Figure 1. Distribution of fruit wines according to the two components (Lievito Secco yeast, 1-blueberry, 2-black chokeberry, 3-blackberry, 4-raspberry, 5-cherry, and 6-apple; + with sugar and enzyme, - without sugar and enzyme).

After conducting the PCA analysis, the wines produced with ICV D254 yeast showed that two separate components were highlighted that had a cumulative diversity of $88.55 \%$. The value of the first component was 4963 , which explained $70.90 \%$ of the diversity, while the value of the second component was 1236 , which explained $17.65 \%$ of the diversity. The first component showed the highest value and described more variables in the PCA analysis, while the second one described less. After orthogonal varimax rotation it was noticed that the first component better described variables of CAT, GPx, FRAP, and SOD. The second component better described variables of MDA, DPPH, and TPC. It is possible to notice in Figure 2 that wines produced from black chokeberry, blueberry, and blackberry were in one group, while in another were wines produced from cherry, raspberry, and apple. This classification is for the same reason as for wines made with Lievito Secco yeast.

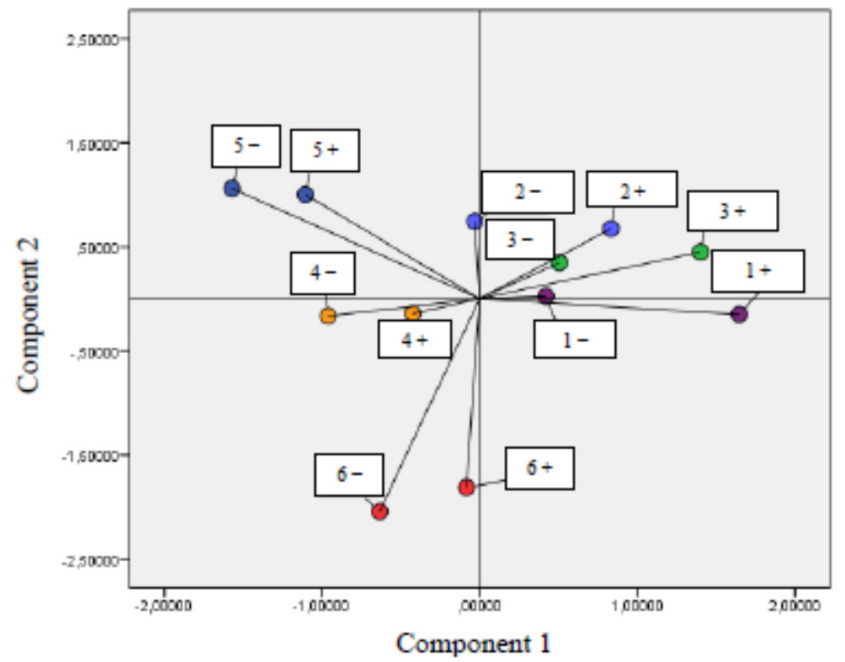

Figure 2. Distribution of fruit wines according to the two components (ICV D254 yeast; 1-blueberry, 2-black chokeberry, 3-blackberry, 4-raspberry, 5-cherry, and 6-apple; + with sugar and enzyme, - without sugar and enzyme). 


\subsection{Correlation between Parameters of Oxidative Stress and Antioxidant Properties-HCA Analysis}

The same variables that were used in the PCA analysis were applied in the HCA. After analysis of the variables for wines produced with both yeasts (i.e., Lievito Secco and ICV D254), HCA dendrograms were obtained. Wines produced from different fruits were grouped in the dendrograms. Similar clusters were connected, so in this case were connected wines that showed similar results. On the first level, three clusters were highlighted in the dendrograms (Figure 3a,b). The first cluster consisted of wines produced from fruits with dark skin (i.e., blueberry, black chokeberry, and blackberry), while in the second one were apple wines. The third cluster consisted of wines produced from raspberry and one from cherry, since these wines showed similar values for parameters (variables) that were applied in the HCA. The cluster with dark-skinned fruits remained specially, while the clusters with apple and raspberry were connected due to the similarity of the results. Regardless of the type of yeast used in wine production, it can be concluded that fruits with a darker skin showed more homogeneous traits compared to raspberry and apple.

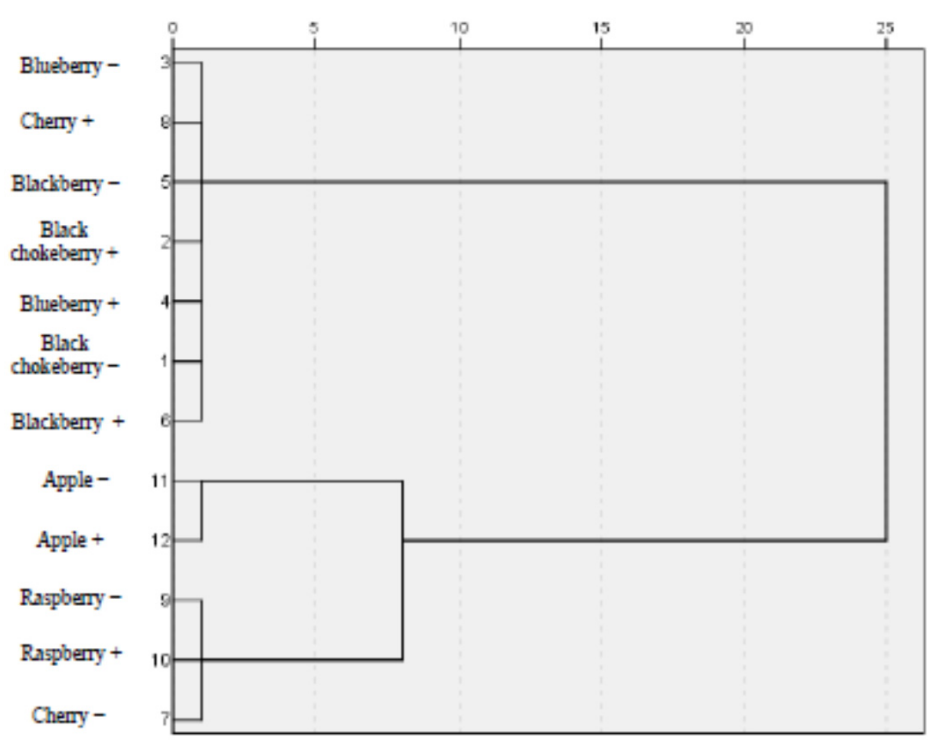

(a)

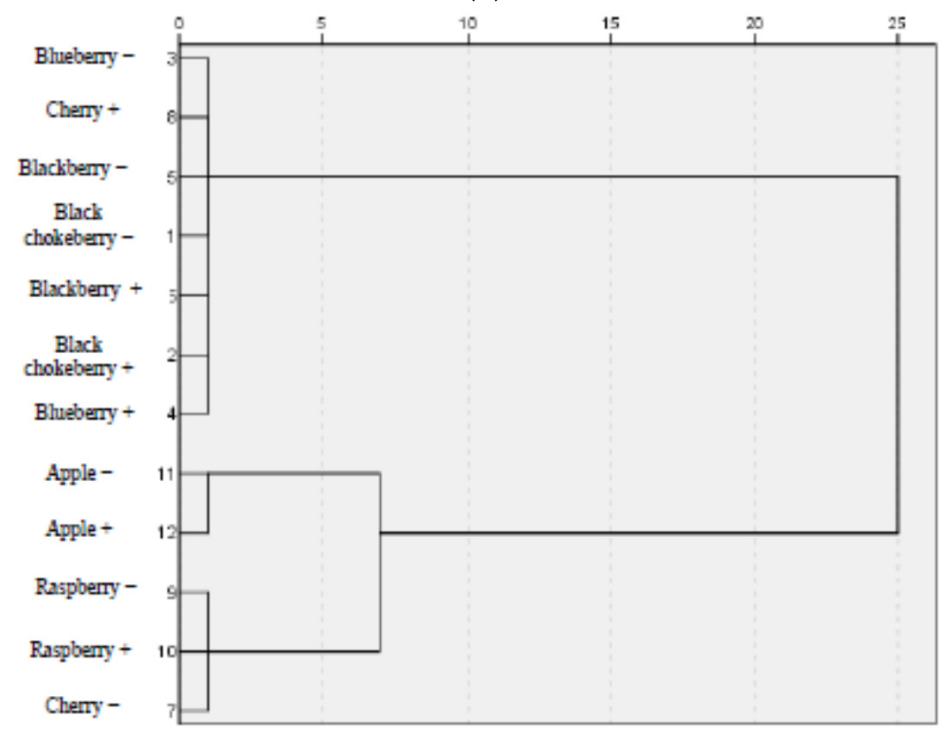

(b)

Figure 3. Dendrograms for the distribution of fruit wines; (a) - Lievito Secco yeast, (b) - ICV D254 yeast; + with sugar and enzyme, - without sugar and enzyme. 


\section{Conclusions}

The results of this study demonstrated that the investigated fruit wines, primarily those produced from berry fruits with the addition of sugar and EPG before fermentation, activated the antioxidant enzymes and decreased reactive oxygen species, inducing membrane lipid damage in synaptosomes. Phytochemicals from blackberry and blueberry wines increased antioxidant enzyme activities the most, while biologically active compounds from black chokeberry exhibited the most powerful protective effect against synaptosomal membrane injury. The berry fruit-induced antioxidant action could be assigned to the synergistic effects of naturally occurring antioxidants in berries. Due to the protective effects against the induced oxidative damage in the isolated neuron terminals, these fruit wines could be considered as promising functional food in the prevention of the harmful effects of oxidative stress and free radical-associated degenerative diseases of the nervous system. Certainly, this in vitro observed protective role of fruit wines presents a good cornerstone for more extensive in vivo studies necessary to prove their therapeutic implications.

Author Contributions: Conceptualization, M.Č., D.K., U.Č. and B.Đ.; methodology, M.Č., D.K. and B.M.; software, D.M. and U.Č.; formal analysis, U.Č. and D.M.; investigation, U.Č., M.Č. and D.K.; resources, B.Đ.; writing—original draft preparation, U.Č.; writing—review and editing, M.Č., D.K., B.Đ. and A.P.; visualization, U.Č. and D.M.; supervision, B.Đ. and A.P.; project administration, B.Đ.; funding acquisition, B.Đ. All authors have read and agreed to the published version of the manuscript.

Funding: This research was funded by the Ministry of Education, Science, and Technological Development of the Republic of Serbia, through grant agreements with the University of Belgrade, Faculty of Pharmacy (no. 451-03-9/2021-14/200161) and INN “Vinča” (no. 451-03-9/2021-14/200017). The APC was funded by a grant agreement with the University of Belgrade, Faculty of Pharmacy (no. 451-03-9/2021-14/200161).

Institutional Review Board Statement: The study was conducted according to the guidelines of the Declaration of Helsinki and approved by the Institutional Review Board of the Ministry of Agriculture, Forestry, and Water Welfare, Veterinary Directorate (protocol code: 323-07-04764/201205, 8 October 2012).

Acknowledgments: The author (Uroš Čakar) gratefully acknowledges Mira Čakar for help and support related to the article writing.

Conflicts of Interest: The authors declare no conflict of interest. The funders had no role in the design of the study; in the collection, analyses, or interpretation of data; in the writing of the manuscript, or in the decision to publish the results.

\section{References}

1. Halliwell, B. How to characterize a biological antioxidant. Free Radic. Res. Commun. 1990, 9, 1-32. [CrossRef]

2. Ighodaro, O.M.; Akinloye, O.A. First line defence antioxidants-superoxide dismutase (SOD), catalase (CAT) and glutathione peroxidase (GPX): Their fundamental role in the entire antioxidant defence grid. Alexandria J. Med. 2017, 54, 287-293. [CrossRef]

3. Allegro, G.; Pastore, C.; Valentini, G.; Filippetti, I. The evolution of phenolic compounds in Vitis vinifera L. red berries during ripening: Analysis and role on wine sensory-A review. Agronomy 2021, 11, 999. [CrossRef]

4. Jabs, T. Reactive oxygen intermediates as mediators of programmed cell death in plants and animals. Biochem. Pharmacol. 1999, 57, 231-245. [CrossRef]

5. Kelsey, N.; Hulick, W.; Winter, A.; Ross, E.; Linseman, D. Neuroprotective effects of anthocyanins on apoptosis induced by mitochondrial oxidative stress. Nutr. Neurosci. 2011, 14, 249-259. [CrossRef] [PubMed]

6. Halliwell, B. Are polyphenols antioxidants or pro-oxidants? What do we learn from cell culture and In Vivo studies? Arch. Biochem. Biophys. 2008, 476, 107-112. [CrossRef] [PubMed]

7. Junli, Y.; Yantao, H.; Chunbo, W.; Wengong, Y. Cytoprotective effect of polypeptide from Chlamys farreri on neuroblastoma (SH-SY5Y) cells following $\mathrm{H}_{2} \mathrm{O}_{2}$ exposure involves scavenging ROS and inhibition JNK phosphorylation. J. Neurochem. 2009, 111, 441-451. [CrossRef]

8. Procházková, D.; Boušová, I.; Wilhelmová, N. Antioxidant and prooxidant properties of flavonoids. Fitoterapia 2011, 82, 513-523. [CrossRef] 
9. Ghinea, I.O.; Ionica Mihaila, M.D.; Blaga Costea, G.-V.; Avramescu, S.M.; Cudalbeanu, M.; Isticioaia, S.-F.; Dinica, R.M.; Furdui, B. HPLC-DAD polyphenolic profiling and antioxidant activities of Sorghum bicolor during germination. Agronomy 2021, $11,417$. [CrossRef]

10. Wang, Y.; Chen, S.; Yu, O. Metabolic engineering of flavonoids in plants and microorganisms. Appl. Microbiol. Biotechnol. 2011, 91, 949. [CrossRef] [PubMed]

11. Yao, L.H.; Jiang, Y.M.; Shi, J.; Tomás-Barberán, F.A.; Datta, N.; Singanusong, R.; Chen, S.S. Flavonoids in food and their health benefits. Plant Foods Hum. Nutr. 2004, 59, 113-122. [CrossRef]

12. de la Portilla, N.; Vaca, R.; Mora-Herrera, M.E.; Salinas, L.; del Aguila, P.; Yañez-Ocampo, G.; Lugo, J. Soil amendment with biosolids and inorganic fertilizers: Effects on biochemical properties and oxidative stress in basil (Ocimum basilicum L.). Agronomy 2020, 10, 1117. [CrossRef]

13. Elavarasan, J.; Velusamy, P.; Ganesan, T.; Ramakrishnan, S.K.; Rajasekaran, D.; Periandavan, K. Hesperidin-mediated expression of Nrf2 and upregulation of antioxidant status in senescent rat heart. J. Pharm. Pharmacol. 2012, 64, 1472-1482. [CrossRef] [PubMed]

14. Doronicheva, N.; Yasui, H.; Sakurai, H. Chemical structure-dependent differential effects of flavonoids on the catalase activity as avaluated by a chemiluminescent method. Biol. Pharm. Bull. 2007, 30, 213-217. [CrossRef]

15. Srikanta, A.H.; Kumar, A.; Sukhdeo, S.V.; Peddha, M.S.; Govindaswamy, V. The antioxidant effect of mulberry and jamun fruit wines by ameliorating oxidative stress in streptozotocin-induced diabetic Wistar rats. Food Funct. 2016, 7, 4422-4431. [CrossRef]

16. Lingua, M.S.; Fabani, M.P.; Wunderlin, D.A.; Baroni, M.V. In Vivo antioxidant activity of grape, pomace and wine from three red varieties grown in Argentina: Its relationship to phenolic profile. J. Funct. Foods 2016, 20, 332-345. [CrossRef]

17. Estruch, R.; Sacanella, E.; Mota, F.; Chiva-Blanch, G.; Antúneza, E.; Casals, E.; Deulofeu, R.; Rotilio, D.; Andres-Lacueva, C.; Lamuela-Raventos, R.M.; et al. Moderate consumption of red wine, but not gin, decreases erythrocyte superoxide dismutase activity: A randomised cross-over trial. Nutr. Metab. Cardiovasc. Dis. 2011, 21, 46-53. [CrossRef]

18. Pourabdolhossein, F.; Ghasemi, A.; Shahroukhi, A.; Sherafat, M.A.; Khoshbaten, A.; Asgari, A. In vitro assessment of paraoxon effects on GABA uptake in rat hippocampal synaptosomes. Toxicol. Vitro 2009, 23, 868-873. [CrossRef]

19. Čolović, M.B.; Vasić, V.M.; Avramović, N.S.; Gajić, M.M.; Djurić, D.M.; Krstić, D.Z. In vitro evaluation of neurotoxicity potential and oxidative stress responses of diazinon and its degradation products in rat brain synaptosomes. Toxicol. Lett. 2015, 233, 29-37. [CrossRef] [PubMed]

20. Čakar, U.; Petrović, A.; Janković, M.; Pejin, B.; Vajs, V.; Čakar, M.; Djordjević, B. Differentiation of wines made from berry and drupe fruits according to their phenolic profiles. Eur. J. Hortic. Sci. 2018, 83, 49-61. [CrossRef]

21. Cohen, R.S.; Blomberg, F.; Berzins, K.; Siekevitz, P. The structure of postsynaptic densities isolated from dog cerebral cortex: I. overall morphology and protein composition. J. Cell Biol. 1977, 74, 181-203. [CrossRef]

22. Towle, A.C.; Sze, P.Y. Steroid binding to synaptic plasma membrane: Differential binding of glucocorticoids and gonadal steroids. J. Steroid Biochem. 1983, 18, 135-143. [CrossRef]

23. Gao, Z.; Huang, K.; Xu, H. Protective effects of flavonoids in the roots of Scutellaria baicalensis Georgi against hydrogen peroxideinduced oxidative stress in HS-SY5Y cells. Pharmacol. Res. 2001, 43, 173-178. [CrossRef]

24. Beutler, E. Red Cell Metabolism. In A Manual of Biochemical Methods, 3rd ed.; Beutler, E., Ed.; Grune and Startton: New York, NY, USA, 1984; pp. 77-136.

25. Wendel, A. Glutathione peroxidase. In Enzymatic Basis of Detoxication; Jakoby, W.B., Ed.; Academic Press: New York, NY, USA, 1980; pp. 333-353.

26. Aruoma, O.I.; Halliwell, B.; Laughton, M.J.; Quinlan, G.J.; Gutteridge, J.M.C. The mechanism of initiation of lipid peroxidation. Evidence against a requirement for an iron(II)-iron(III) complex. Biochem. J. 1989, 258, 617-620. [CrossRef]

27. Lowry, O.H.; Rosebrough, N.J.; Farr, A.L.; Randall, R.J. Protein measurement with the folin phenol reagent. J. Biol. Chem. 1951, 193, 265-275. [CrossRef]

28. Cho, B.O.; Ryu, H.W.; Jin, C.H.; Choi, D.S.; Kang, S.Y.; Kim, D.S.; Byun, M.-W.; Jeong, I.Y. Blackberry extract attenuates oxidative stress through up-regulation of Nrf2-dependent antioxidant enzymes in carbon tetrachloride-treated rats. J. Agric. Food Chem. 2011, 59, 11442-11448. [CrossRef]

29. Noguer, M.A.; Cerezo, A.B.; Donoso Navarro, E.; Garcia-Parrilla, M.C. Intake of alcohol-free red wine modulates antioxidant enzyme activities in a human intervention study. Pharmacol. Res. 2012, 65, 609-614. [CrossRef]

30. Sangiovanni, E.; Vrhovsek, U.; Rossoni, G.; Colombo, E.; Brunelli, C.; Brembati, L.; Trivulzio, S.; Gasperotti, M.; Mattivi, F.; Bosisio, E.; et al. Ellagitannins from Rubus berries for the control of gastric inflammation: In Vitro and In Vivo studies. PLoS ONE 2013, 8, e71762. [CrossRef]

31. Mendes, D.; Oliveira, M.M.; Moreira, P.I.; Coutinho, J.; Nunes, F.M.; Pereira, D.M.; Valentão, P.; Andrade, P.B.; Videira, R.A. Beneficial effects of white wine polyphenols-enriched diet on Alzheimer's disease-like pathology. J. Nutr. Biochem. 2018, 55, 165-177. [CrossRef]

32. Kardum, N.; Takić, M.; Šavikin, K.; Zec, M.; Zdunić, G.; Spasić, S.; Konić-Ristić, A. Effects of polyphenol-rich chokeberry juice on cellular antioxidant enzymes and membrane lipid status in healthy women. J. Funct. Foods 2014, 9, 89-97. [CrossRef]

33. Miller, M.G.; Shukitt-Hale, B. Berry fruit enhances beneficial signaling in the brain. J. Agric. Food Chem. 2012, 60, 5709-5715. [CrossRef] 
34. de Figueiredo, E.A.; Alves, N.F.B.; de Monteiro, M.M.O.; de Cavalcanti, C.O.; da Silva, T.M.S.; da Silva, T.M.G.; de Braga, V.A.; Oliveira, E. Antioxidant and antihypertensive effects of a chemically defined fraction of syrah red wine on spontaneously hypertensive rats. Nutrients 2017, 9, 574. [CrossRef]

35. Tenore, G.C.; Manfra, M.; Stiuso, P.; Coppola, L.; Russo, M.; Ritieni, A.; Campiglia, P. Polyphenolic pattern and In Vitro cardioprotective properties of typical red wines from vineyards cultivated in Scafati (Salerno, Italy). Food Chem. 2013, 140, 803-809. [CrossRef] [PubMed]

36. Čakar, U.; Grozdanić, N.; Pejin, B.; Vasić, V.; Čakar, M.; Petrović, A.; Djordjević, B. Impact of vinification procedure on fruit wine inhibitory activity against $\alpha$-glucosidase. Food Biosci. 2018, 25, 1-7. [CrossRef]

37. Zheng, W.; Wang, S.Y. Oxygen Radical Absorbing Capacity of Phenolics in Blueberries, Cranberries, Chokeberries, and Lingonberries. J. Agric. Food Chem. 2003, 51, 502-509. [CrossRef] [PubMed]

38. Kähkönen, M.P.; Hopia, A.I.; Heinonen, M. Berry Phenolics and Their Antioxidant Activity. J. Agric. Food Chem. 2001, 49, 4076-4082. [CrossRef]

39. Häkkinen, S.; Heinonen, M.; Kärenlampi, S.; Mykkänen, H.; Ruuskanen, J.; Törrönen, R. Screening of selected flavonoids and phenolic acids in 19 berries. Food Res. Int. 1999, 32, 345-353. [CrossRef]

40. Szwajgier, D.; Halinowski, T.; Helman, E.; Tylus, K.; Tymcio, A. Influence of different heat treatments on the content of phenolic acids and their derivatives in selected fruits. Fruits 2014, 69, 167-178. [CrossRef]

41. Grunovaite, L.; Pukalskienè, M.; Pukalskas, A.; Venskutonis, P.R. Fractionation of black chokeberry pomace into functional ingredients using high pressure extraction methods and evaluation of their antioxidant capacity and chemical composition. J. Funct. Foods 2016, 24, 85-96. [CrossRef]

42. Klarić, D.A.; Klarić, I.; Mornar, A. Polyphenol content and antioxidant activity of commercial blackberry wines from Croatia: Application of multivariate analysis for geographic origin differentiation. J. Food Nutr. Res. 2011, 50, 199-209.

43. Zadernowski, R.; Naczk, M.; Nesterowicz, J. Phenolic Acid Profiles in Some Small Berries. J. Agric. Food Chem. 2005, 53, 2118-2124. [CrossRef]

44. El Gharras, H. Polyphenols: Food sources, properties and applications-A review. Int. J. Food Sci. Technol. 2009, 44, 2512-2518. [CrossRef]

45. Mattila, P.; Kumpulainen, J. Determination of Free and Total Phenolic Acids in Plant-Derived Foods by HPLC with Diode-Array Detection. J. Agric. Food Chem. 2002, 50, 3660-3667. [CrossRef]

46. Gu, L.; Kelm, M.A.; Hammerstone, J.F.; Beecher, G.; Holden, J.; Haytowitz, D.; Prior, R.L. Screening of Foods Containing Proanthocyanidins and Their Structural Characterization Using LC-MS/MS and Thiolytic Degradation. J. Agric. Food Chem. 2003, 51, 7513-7521. [CrossRef]

47. Arts, I.C.W.; van de Putte, B.; Hollman, P.C.H. Catechin Contents of Foods Commonly Consumed in The Netherlands. 1. Fruits, Vegetables, Staple Foods, and Processed Foods. J. Agric. Food Chem. 2000, 48, 1746-1751. [CrossRef]

48. Thilakarathna, S.H.; Rupasinghe, H.P.V. Anti-atherosclerotic effects of fruit bioactive compounds: A review of current scientific evidence. Can. J. Plant Sci. 2012, 92, 407-419. [CrossRef]

49. Czyzowska, A.; Pogorzelski, E. Changes to polyphenols in the process of production of must and wines from blackcurrants and cherries. Part I. Total polyphenols and phenolic acids. Eur. Food Res. Technol. 2002, 214, 148-154. [CrossRef]

50. Xiao, Z.; Fang, L.; Niu, Y.; Yu, H. Effect of cultivar and variety on phenolic compounds and antioxidant activity of cherry wine. Food Chem. 2015, 186, 69-73. [CrossRef]

51. Shahidi, F. Nutraceuticals and functional foods: Whole versus processed foods. Trends Food Sci. Technol. 2009, 20, 376-387. [CrossRef]

52. Su, M.-S.; Chien, P.-J. Antioxidant activity, anthocyanins, and phenolics of rabbiteye blueberry (Vaccinium ashei) fluid products as affected by fermentation. Food Chem. 2007, 104, 182-187. [CrossRef]

53. Moreno-Arribas, M.V.; Polo, M.C. Winemaking Biochemistry and Microbiology: Current Knowledge and Future Trends. Crit. Rev. Food Sci. Nutr. 2005, 45, 265-286. [CrossRef] [PubMed]

54. Eder, R.; Wendelin, S.; Vrhovsek, U. Influence of viticultural and enological factors on the concentration of resveratrols in grapes and wine. In Proceedings of the 25th Congres Mondial de la Vigne et du Vin, Paris, France, 19-23 June 2000; pp. 79-86.

55. Sun, L.; Zhang, J.; Lu, X.; Zhang, L.; Zhang, Y. Evaluation to the antioxidant activity of total flavonoids extract from persimmon (Diospyros kaki L.) leaves. Food Chem. Toxicol. 2011, 49, 2689-2696. [CrossRef] [PubMed] 